\title{
AMELIORATIVE EFFECT OF PHOENIX DACTYLIFERA ON ADVERSE EFFECTS OF LINEZOLID IN MALE ALBINO RATS
}

\author{
MAHMOUD AHMED ABDO SAID*, SAYED A. AZIZ, SAMEH M. ELNABTITY
}

Department of Pharmacology, Faculty of Veterinary Medicine, Zagazig University, Egypt. Email: ph.mahmoud.91@gmail.com Received: 19 February 2019, Received and Accepted: 14 March 2019

ABSTRACT

Objective: This study aimed to investigate the adverse effects of linezolid (LZD) on biochemical and hematological parameters and some organs including bone marrow, brain, and kidneys and to investigate the possibility of methanolic extract of Phoenix dactylifera (MEPD) to counteract the adverse effects of LZD.

Methods: Forty-eight adult male albino rats were allocated into four equal groups (each of 12 animals). The first group received Tween 80 orally. The second group received was given $0.5 \mathrm{ml}$ of LZD suspension $4 \%$ in Tween $80(100 \mathrm{mg} / \mathrm{kg}$ body weight) orally. The third group received the same dose of LZD suspension followed by $1 \mathrm{ml}$ of MEPD orally. The rats in the last group were given $1 \mathrm{ml}$ of MEPD (1000 mg/kg body weight) orally. Rats were sacrificed and blood samples were collected for hematological and biochemical study. Femur bones, brain, and kidneys were dissected and kept in a jar containing $10 \%$ formalin to perform the histopathological investigation.

Results: The dose of LZD administered for 14 successive days induced a mild-to-moderate hematological abnormalities including decrease in hemoglobin content $(7.88 \pm 0.18 \mathrm{~g} / \mathrm{L})$ on day- 1 post-treatment. Significant increase in serum urea (59.75 \pm 0.85$)$ and serum creatinine was observed (1.89 \pm 0.04$)$. On day-14 post-treatment, LZD induced mild-to-moderate cellular abnormalities in bone marrow, brain, and kidneys. The concurrent oral administration of MEPD and LZD for the same period corrected the hematological, biochemical, and histopathological alterations induced by LZD.

Conclusion: It was concluded that MEPD clearly ameliorated these damaging effects induced by LZD.

Keywords: Phoenix dactylifera, Linezolid, urea, Creatinine, Brain, Bone marrow.

(C) 2019 The Authors. Published by Innovare Academic Sciences Pvt Ltd. This is an open access article under the CC BY license (http://creativecommons. org/licenses/by/4. 0/) DOI: http://dx.doi.org/10.22159/ijap.2019.v11s5.T0023

\section{INTRODUCTION}

The oxazolidinones represent a new synthetic class of antibacterial agents with activity against Gram-positive organisms [1]. Studies have shown that the oxazolidinones: Linezolid (LZD) and eperezolid are active against vancomycin-resistant staph aureus and penicillinresistant Streptococcus pneumoniae [2].

LZD is entering Phase III clinical trials as a therapeutic agent that is effective against skin infections, bacteremia, and pneumonia caused by Gram-positive pathogenic bacteria, the antimicrobial activities of the oxazolidinones were first described by scientists at Dupont de Nemours Co., Inc., USA [3].

LZD was discovered in the 1990s and first approved for use in 2000 . It was the first commercially available 1,3-oxazolidinone antibiotic, although others are in development. As a protein synthesis inhibitor, it stops the growth of bacteria by disrupting their production of proteins, that is, a bacteriostatic agent, not bactericidal. Although many antibiotics work this way, the exact mechanism of the action of LZD appears to be unique in that it blocks the initiation step of protein production and not one of the later steps [4]. Resistance to LZD is extremely rare [5].

In Japan, the use of LZD for MRSA infections was approved in April 2006. Because the mechanism of the action of LZD differs from that of current protein synthesis inhibitors, it is considered to have no crossresistance with existing antimicrobial agents [6].

Data on long-term use are limited, but serious neuropathies (e.g., peripheral and optic neuropathies), myelosuppression, and hyperlactatemia have been observed [7] and are considered to be related to the inhibition of mitochondrial protein synthesis [8].
Phoenix dactylifera (PD) is also known as date palm. It is a monocotyledon plant within the palm tree family and they can be found mostly in North Africa and the Middle East region [9]. They are among a few plants that could survive the harsh arid environment and thus are highly regarded for the nutritional value that the palm tree fruit provides. In these arid regions, where foods are scarce, date palm serves as a good food source as they are rich in carbohydrates and they have even become a part of Arabian diet. Aside from a common food source, date palm fruits have been used traditionally to treat various types of ailments and it has been regarded that consumption of the fruit is good for health [10].

Traditional medicines are gaining importance and nowadays are being studied to find the scientific basis of their therapeutic actions. The use of herbal medicine has become increasingly popular worldwide, especially in the Asian and African countries. The various parts of PD are widely used in traditional medicine for the treatment of various disorders which include memory disturbances, fever, and inflammation [11].

Muslims believe that "he who eats seven dates every morning will not be affected by poison or magic on the day he eats them" [12].

The aim of this study is to investigate the possible adverse effects of LZD on different biological functions in rats and to find out the possible role of PD methanolic extract in counteracting these possible adverse effects.

\section{MATERIALS AND METHODS}

Drugs

LZD $^{\circledR}$ (Global Napi, Egypt), available as tablets (600 mg/tablet).

Dose: $100 \mathrm{mg} / \mathrm{kg}$ b.wt [13].

Tween 80 (Al-Gomhoria Co. Ltd., Egypt). 
Methyl alcohol (Al-Gomhoria Co. Ltd., Egypt). PD (Siwa oasis, Egypt).

\section{PD fruits}

Dose: $1000 \mathrm{mg} / \mathrm{Kg}$ (as $25 \%$ solution) [14].

\section{Methods}

Method of methanolic extraction of PD fruits

About $1 \mathrm{Kg}$ of fresh fruits of PD and pits were prepared and the fresh PD fruit (PDF) seeds were removed. The known weight of flesh PDFs (FPDFs) was soaked in $1 \mathrm{~L}$ methanol (79\%) and left for $3 \mathrm{~h}$; then, the mixture was blended in a stainless steel blender and the blended mixture was sieved twice by narrow mesh stainless steel sieve and the sieved part was then added to $2 \mathrm{~L}$ of methyl alcohol $79 \%$. The mixture was then filtered through sterile absorbed gauze. The residual part of dates was soaked in $3 \mathrm{~L}$ of methanol $79 \%$ and left for $2 \mathrm{~h}$ at $20^{\circ} \mathrm{C}$, and then reblended and refrigerated using the clean gauze. The filtrate was added to the previous prepared filtrate and the residual non-filtered part was weighed and discarded. The clean part of the supernatant was put in the rotary evaporator and adjusted to $42^{\circ} \mathrm{C}$, then left for methanol to be evaporated. Finally, the resultant crude dates methanolic extract was then measured, weighed, and kept in the laboratory refrigerator till needed to be administered orally to male albino rats.

\section{Animals and experimental design}

Before starting the experiment, we obtained ethical approval from Zagazig University, Egypt. Forty-eight adult male albino rats Wistar strain weighing 180-200 g were allocated into four equal groups; each of 12 animals. The first group was left as control and was given $0.5 \mathrm{ml}$ Tween 80 orally using the stomach tube daily for 14 consecutive days. The second group was given $0.5 \mathrm{ml}$ of LZD $(100 \mathrm{mg} / \mathrm{kg}$ body weight) suspension $4 \%$ in Tween 80 P0 daily for 14 consecutive days. The third group received $0.5 \mathrm{ml}$ of LZD (100 mg/kg body weight) suspension $4 \%$ in Tween 80 followed by $1 \mathrm{ml}$ of methanolic extract of PD (MEPD) (1000 mg/Kg) orally using the stomach tube daily for 14 consecutive days. The rats in the last group were administered $1 \mathrm{ml}$ of PD methanolic extract $(1000 \mathrm{mg} / \mathrm{Kg})$ daily for 14 consecutive days by oral gavage using the stomach tube.

\section{Sampling}

On day-1, 7, and 14 post-treatment, four rats from each group were sacrificed and two blood samples were collected into two test tubes (EDTA test tube to be used for hematological studies and plain test tube without anticoagulant to obtain serum for biochemical studies). After that, rats were dissected to remove femur bones, brain, and kidneys to be kept in a jar containing neutral formalin $10 \%$ at the same periods to be used for histopathological study.

\section{Hematological studies}

Hematological autoanalyzer (Automatic cell counter: Sysmex KX 21 N, Sysmex Co., Japan) was used to determine hematological parameters such as red blood cells (RBCs), white blood cells (WBCs), hemoglobin (HGB), mean corpuscular volume (MCV), mean corpuscular hemoglobin $(\mathrm{MCH})$, mean corpuscular hemoglobin concentration $(\mathrm{MCHC})$, and platelets (PLT) [15].

\section{Biochemical study}

Serum urea and creatinine were measured using diagnostic kits (Spectrum Diagnostics, Obour City, Egypt) [16,17].

\section{Histopathological studies}

The formalin preserved the bone marrow, brain, and kidney tissues and they were processed in an automated tissue processor. The processing consisted of an initial two-step fixation and dehydration. Fixation comprising tissue immersion in $10 \%$ buffered formalin for $48 \mathrm{~h}$ followed by removal of fixative in distilled water for $30 \mathrm{~min}$. Dehydration was then carried out by running the tissues through a graded series of alcohol (70\%, 90\%, and 100\%). The tissue was initially exposed to $70 \%$ alcohol for 120 min followed by $90 \%$ alcohol for 90 min and then two cycles of absolute alcohol, each for $1 \mathrm{~h}$. Dehydration was then followed by clearing the samples in several changes of xylene. It consisted of tissue immersion for an hour in a mixture comprising $50 \%$ alcohol and $50 \%$ xylene followed by pure xylene for $1 \frac{1}{2} \mathrm{~h}$. Samples were then impregnated with molten paraffin wax, then embedded and blocked out. Paraffin sections $(4-5 \mu \mathrm{m})$ were stained with hematoxylin and eosin [18]. Stained sections were examined for inflammatory reactions, degenerative, necrotic, apoptotic changes, and any other pathological lesions in the examined tissues of experimental rats.

\section{Statistical analysis}

Data were analyzed using computerized SPSS programs version 21 (2001). The results were expressed as mean \pm standard error of mean. The total variation was analyzed by performing one-way analysis of variance. Duncan test was used for determining significance. $\mathrm{p}<0.05$ was considered statistically significant [19].

\section{RESULTS AND DISCUSSION}

It has been revealed that the oral administration of various treatments given daily for 14 days to male albino rats in their recommended doses induced non-significant change in thin-layer chromatography except with LZD which induced a significant increase $(p<0.05)$ along the entire period of the study compared with control group. This elevation may be due to posterior leukoencephalopathy induced by LZD [20]. Arshad et al. [21] supported our results because they reported that MEPD fruits decreased total leukocytic count due to its anti-inflammatory effect. LZD is known to cause oxidative stress; this oxidation results in increased total leukocytic count, Table 1 [22].

Regarding the HGB concentration, it is clear that the administration of LZD, MEPD, and their combination for 14 days displayed non-significant change during the entire period of the study related to control group except with LZD after the $1^{\text {st }}$ day and its combination with MEPD after 7 days post-treatment which showed a significant decrease and increase $(\mathrm{p}<0.05)$, respectively, corresponding to control group. A significant decrease was observed on day-1 post-treatment with LZD; similar results were previously recorded by Birmingham et al. [23] and MacDougall and Chambers [24], who reported that one of the adverse effects induced by LZD is anemia. Regarding the group received LZD with MEPD that was agreeable with Ufelle et al. [25], who reported that MEPD seeds raised the HGB concentration in Wistar rats stating the hematopoietic effect of PD.

MCV and MCH value of all groups was not significantly affected along the entire course of the study in response to various treatments except with LZD after the $1^{\text {st }}$ day post-treatment which displayed a significant decrease $(\mathrm{p}<0.05)$ compared with control group that coordinated with Kofteridis et al. [26], who stated that LZD decreased MCV, PCV, MCH, and MCHC. No significant change occurred in MCHC of LZD-treated group that needs further investigations.

Our results were not in match with French [27] with reference to the PLT count because they mentioned that oral administration of LZD $600 \mathrm{mg}$ twice daily PO induced thrombocytopenia after 28 days in humans.

The total RBCs count was not significantly changed along the course of the study in response to various treatments except with LZD which showed a significant increase on day-7 post-treatment $(p<0.05)$ compared with control group. This theory is a compensatory mechanism secondary to decreased HGB concentration that leads to increase in erythropoietin [28].

Serum urea of LZD-treated group has significantly raised in comparison to control group, while the oral administration of LZD and its combination with MEPD in their recommended doses and time elicited a non-significant change compared with control group, whereas the administration of MEPD alone induced non-significant changes when compared with control group and a significant decrease when compared with LZD or its combination after 7 and 14 days posttreatment, Table 2. 
On day-1 post-treatment, the dose of LZD given daily for 14 days caused a significant increase in serum creatinine. However, various treatments induced non-significant changes when compared with control group except combination of LZD and MEPD which induced a significant decrease corresponding to control group and LZD-treated group. On day-14, several treatments induced a significant increase when compared with control group except MEPD alone which induced a nonsignificant change with control group and a significant decrease when compared with LZD alone and its combination with MEPD.

Our results of the kidney function tests agreed with those established by Natsumoto et al. [29], who reported that LZD increased serum creatinine level in patients received LZD for 7 weeks and this contributes to that LZD can cause interstitial nephritis after 3 days as reported by Nayak et al. [30]. On administration of LZD and PD combination, our recorded results showed a significant decrease in creatinine level, this suggested that PD fruits have nephroprotective effect as investigated by Al-Qarawi et al. [31], who studied the effect of an extract of the flesh and pits of PD on gentamicin-induced nephrotoxicity in rats were effective in reducing the increased serum creatinine. Furthermore, our results informed that LZD caused a significant increase in the serum urea; these results agreed with Lin et al. [32], who stated that LZD mildly elevated urea 14 days after administration in patients with renal impairment.

\section{Histopathological results}

\section{Bone marrow}

The bone marrow section of the control group showed numerous megakaryocytes with white blood cell and RBCs (Fig. 1a). After 7 days post-treatment, the bone marrow section showed hypocellular bone

Table 1: Effects of oral administration of linezolid (100 mg/Kg body wt), PD methanolic extract (1000 mg/kg body wt), and their combination given daily for 14 successive days in some hematological parameters of rats on day-1, 7, and 14 post-treatment. (Mean $\pm S E)(n=4)$

\begin{tabular}{|c|c|c|c|c|}
\hline \multirow{2}{*}{$\begin{array}{l}\text { Period } \\
\text { Group } \\
\text { parameter }\end{array}$} & \multicolumn{4}{|l|}{ Day-1 } \\
\hline & Control & LZD & LZD+MEPD & PD \\
\hline $\operatorname{TLC}(\mu \mathrm{l})$ & $9.60 \pm 1.20^{\mathrm{b}}$ & $17.83 \pm 0.52^{\mathrm{a}}$ & $12.00 \pm 0.56^{\mathrm{b}}$ & $11.10 \pm 0.43^{\mathrm{b}}$ \\
\hline HGB $(\mathrm{g} / \mathrm{l})$ & $12.93 \pm 0.36^{\mathrm{ab}}$ & $7.88 \pm 0.18^{\mathrm{c}}$ & $13.55 \pm 0.27^{\mathrm{ab}}$ & $14.28 \pm 0.35^{\mathrm{a}}$ \\
\hline RBCs count $(\mu \mathrm{l})$ & $6.83 \pm 0.26^{\mathrm{a}}$ & $8.03 \pm 0.27^{a}$ & $7.28 \pm 0.42^{\mathrm{a}}$ & $7.93 \pm 0.10^{\mathrm{a}}$ \\
\hline $\operatorname{MCV}(\mathrm{fl})$ & $59.38 \pm 1.08^{\mathrm{a}}$ & $55.40 \pm 0.89^{\mathrm{b}}$ & $60.95 \pm 0.67^{\mathrm{a}}$ & $59.85 \pm 0.85^{\mathrm{a}}$ \\
\hline $\mathrm{MCH}(\mathrm{pg})$ & $18.03 \pm 0.22^{\mathrm{a}}$ & $15.98 \pm 0.55^{b}$ & $18.83 \pm 0.73^{\mathrm{a}}$ & $18.08 \pm 0.22^{\mathrm{a}}$ \\
\hline MCHC (g/dl) & $31.05 \pm 0.27^{\mathrm{a}}$ & $26.62 \pm 0.53^{a}$ & $30.65 \pm 0.94^{\mathrm{a}}$ & $30.13 \pm 0.26^{\mathrm{a}}$ \\
\hline $\operatorname{PLT}(\mu \mathrm{l})$ & $571.50 \pm 26.11^{\mathrm{b}}$ & $709.75 \pm 3.94^{\mathrm{a}}$ & $621.25 \pm 30.18^{\mathrm{ab}}$ & $648.75 \pm 19.35^{\mathrm{ab}}$ \\
\hline Period & \multicolumn{4}{|l|}{ Day-7 } \\
\hline $\begin{array}{l}\text { Group } \\
\text { parameter }\end{array}$ & Control & LZD & LZD+MEPD & PD \\
\hline $\operatorname{TLC}(\mu \mathrm{l})$ & $9.60 \pm 1.20^{\mathrm{b}}$ & $17.78 \pm 0.72^{\mathrm{a}}$ & $12.08 \pm 0.05^{\mathrm{b}}$ & $9.56 \pm 1.30^{\mathrm{b}}$ \\
\hline $\mathrm{HGB}(\mathrm{g} / \mathrm{l})$ & $12.93 \pm 0.36^{\mathrm{b}}$ & $15.30 \pm 0.41^{\mathrm{a}}$ & $15.78 \pm 0.38^{\mathrm{a}}$ & $12.53 \pm 0.24^{\mathrm{b}}$ \\
\hline $\operatorname{MCV}(\mathrm{fl})$ & $59.38 \pm 1.08^{\mathrm{a}}$ & $54.1 \pm 0.46^{\mathrm{b}}$ & $57.25 \pm 1.06^{\mathrm{a}}$ & $59.38 \pm 1.08^{\mathrm{a}}$ \\
\hline $\mathrm{MCH}(\mathrm{pg})$ & $18.03 \pm 0.22^{\mathrm{a}}$ & $17.98 \pm 0.25^{\mathrm{a}}$ & $18.55 \pm 0.32^{\mathrm{a}}$ & $18.03 \pm 0.22^{\mathrm{a}}$ \\
\hline $\mathrm{MCHC}(\mathrm{g} / \mathrm{dl})$ & $31.05 \pm 0.27^{b}$ & $31.25 \pm 0.46^{\mathrm{ab}}$ & $32.55 \pm 0.26^{a}$ & $31.01 \pm 0.12^{\mathrm{b}}$ \\
\hline $\operatorname{PLT}(\mu \mathrm{l})$ & $571.50 \pm 26.11^{b}$ & $757.75 \pm 15.94^{a}$ & $447.00 \pm 17.23^{c}$ & $569.44 \pm 24.12^{\mathrm{b}}$ \\
\hline Period & \multicolumn{4}{|l|}{ Day-14 } \\
\hline $\begin{array}{l}\text { Group } \\
\text { parameter }\end{array}$ & Control & LZD & LZD+MEPD & PD \\
\hline TLC $(\mu \mathrm{l})$ & $11.33 \pm 0.59^{b}$ & $15.40 \pm 0.76^{\mathrm{a}}$ & $12.70 \pm 0.83^{\mathrm{ab}}$ & $11.48 \pm 0.89^{b}$ \\
\hline $\operatorname{HGB}(\mathrm{g} / \mathrm{l})$ & $13.40 \pm 0.64^{\mathrm{a}}$ & $13.10 \pm 0.17^{\mathrm{a}}$ & $14.45 \pm 0.32^{\mathrm{a}}$ & $13.83 \pm 0.50^{\mathrm{a}}$ \\
\hline RBCs count $(\mu \mathrm{l})$ & $7.44 \pm 0.41^{\mathrm{a}}$ & $7.22 \pm 0.14^{\mathrm{a}}$ & $8.13 \pm 0.33^{\mathrm{a}}$ & $7.69 \pm 0.22^{\mathrm{a}}$ \\
\hline MCV (fl) & $56.33 \pm 0.71^{\mathrm{a}}$ & $57.43 \pm 0.72^{\mathrm{a}}$ & $56.48 \pm 1.39^{a}$ & $57.05 \pm 1.11^{\mathrm{a}}$ \\
\hline $\mathrm{MCH}(\mathrm{pg})$ & $17.88 \pm 0.24^{\mathrm{a}}$ & $18.18 \pm 0.31^{\mathrm{a}}$ & $17.83 \pm 0.50^{\mathrm{a}}$ & $17.95 \pm 0.31^{\mathrm{a}}$ \\
\hline MCHC (g/dl) & $31.13 \pm 0.43^{\mathrm{a}}$ & $31.65 \pm 0.44^{\mathrm{a}}$ & $31.58 \pm 0.39^{a}$ & $31.50 \pm 0.12^{\mathrm{a}}$ \\
\hline PLT $(\mu \mathrm{l})$ & $705.00 \pm 14.34^{\mathrm{a}}$ & $578.00 \pm 31.37^{b}$ & $719.00 \pm 33.08^{a}$ & $623.25 \pm 31.05^{\mathrm{ab}}$ \\
\hline
\end{tabular}

Means within the same column carrying different superscripts are significantly different at $\mathrm{p}<0.05$, PD: Phoenix dactylifera, TLC: Thin-layer chromatography, HGB: Hemoglobin, MCV: Mean corpuscular volume, MCHC: Mean corpuscular hemoglobin concentration, PLT: Platelets, RBCs: Red blood cells, MCV: Mean corpuscular volume, MCH: Mean corpuscular hemoglobin

Table 2: Effects of oral administration of LZD (100 mg/Kg body wt), PD methanolic extract (1000 $\mathrm{mg} / \mathrm{kg}$ body wt), and their combination given daily for 14 successive days on serum urea and creatinine of rats on day-1, 7, and 14 post-treatment. (Mean $\pm S E)(n=4)$

\begin{tabular}{|c|c|c|c|c|c|c|}
\hline \multirow{3}{*}{$\begin{array}{l}\text { Parameter } \\
\text { Group }\end{array}$} & \multirow{2}{*}{\multicolumn{3}{|c|}{$\begin{array}{l}\text { Serum urea }(\mathrm{mg} / \mathrm{dl}) \\
\text { Time-post-treatment }\end{array}$}} & \multicolumn{3}{|c|}{ Serum creatinine $(\mathrm{mg} / \mathrm{dl})$} \\
\hline & & & & \multicolumn{3}{|c|}{ Time-post-treatment } \\
\hline & $1^{\text {st }}$ day & $7^{\text {th }}$ day & $14^{\text {th }}$ day & $1^{\text {st }}$ day & $7^{\text {th }}$ day & $14^{\text {th }}$ day \\
\hline Control & $27.00 \pm 0.71^{\mathrm{b}}$ & $27.00 \pm 0.71^{\mathrm{b}}$ & $45.50 \pm 1.04^{\mathrm{bc}}$ & $0.75 \pm 0.06^{b}$ & $0.75 \pm 0.06^{\mathrm{a}}$ & $0.85 \pm 0.02^{c}$ \\
\hline LZD & $36.75 \pm 1.44^{\mathrm{a}}$ & $42.68 \pm 1.38^{\mathrm{a}}$ & $59.75 \pm 0.85^{\mathrm{a}}$ & $1.23 \pm 0.04^{\mathrm{a}}$ & $0.74 \pm 0.01^{\mathrm{a}}$ & $1.89 \pm 0.04^{\mathrm{a}}$ \\
\hline $\mathrm{LZD}+\mathrm{PD}$ & $37.75 \pm 2.95^{\mathrm{a}}$ & $44.65 \pm 5.01^{\mathrm{a}}$ & $48.75 \pm 1.11^{b}$ & $1.16 \pm 0.09^{a}$ & $0.57 \pm 0.02^{\mathrm{b}}$ & $1.35 \pm 0.02^{b}$ \\
\hline $\mathrm{PD}$ & $31.00 \pm 2.12^{\mathrm{ab}}$ & $27.77 \pm 0.83^{b}$ & $41.00 \pm 1.58^{c}$ & $0.97 \pm 0.10^{\mathrm{ab}}$ & $0.75 \pm 0.06^{\mathrm{a}}$ & $0.96 \pm 0.05^{c}$ \\
\hline
\end{tabular}

Means within the same column carrying different superscripts are significantly different at p<0.05. LZD: Linezolid, PD: Phoenix dactylifera 


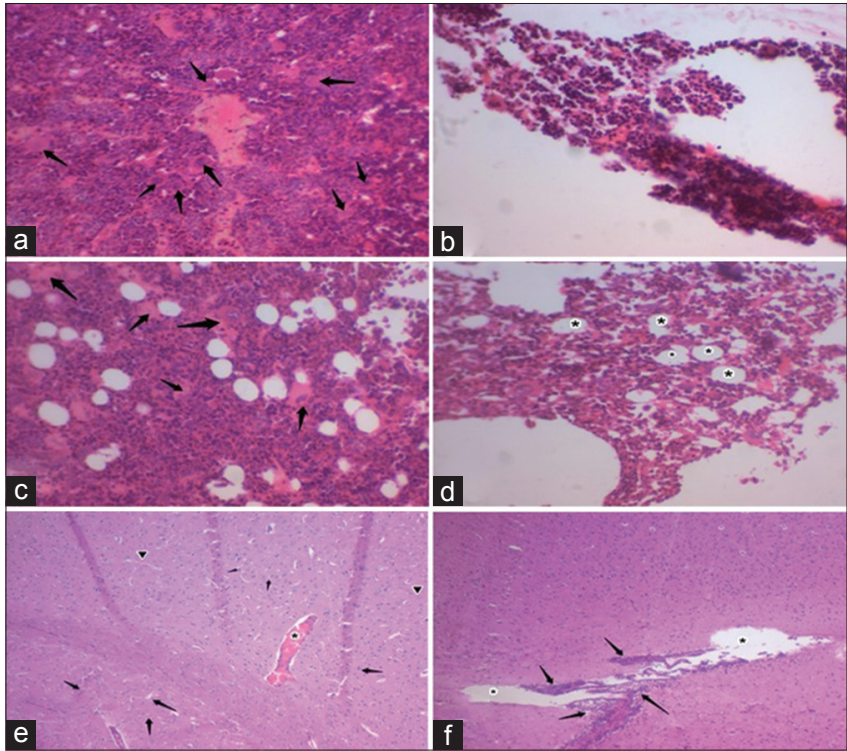

Fig. 1: (a) Photomicrograph of normal bone marrow of control group showing numerous megakaryocytes $\uparrow$ with white blood cell and red blood cell (RBC) elements ( $H$ and $E, \times 400)$. (b) Photomicrograph of bone marrow from rats 7 days posttreatment treated with linezolid (LZD) showing hypocellular bone marrow elements (H and E, ×400). (c) Photomicrograph of normal bone marrow from rats 1 day post-treatment with Phoenix showing normal cellularity of the bone marrow with numerous megakaryocytes $\uparrow$ surrounded by white blood cells and RBC elements (H and E, ×400). (d) Photomicrograph of bone marrow treated with LZD and Phoenix 7 days post-treatment showing moderate increase in the bone marrow elements with scattered fat cells* $(H$ and $E, \times 200)$. (e) Photomicrograph of normal brain tissue from control group showing normal neuron cells $\uparrow$ surrounded by neurological fibers $\Delta$ with elongated vascular space filled with RBCs* $(H$ and $E \times 200)$.

(f) Photomicrograph of brain tissue treated with LZD at the

$1^{\text {st }}$ day post-treatment showing aggregates of inflammatory cells $\uparrow$ surrounding dilated vascular space* $(H$ and $E, \times 200)$

marrow elements with LZD alone (Fig. 1b). However, the combination of both LZD and MEPD, the bone marrow section showed moderate increase in the bone marrow elements and scattered fat cells (Fig. 1d), whereas normal bone marrow was normal cellularity and numerous megakaryocytes surrounded by white blood cell and RBC elements were observed as a result of treatment with Phoenix alone after the $7^{\text {th }}$ day post-treatment (Fig. 1c). Patel and Makhija, [13] supported our results, where they found that $100 \mathrm{mg} / \mathrm{kg}$ dose of LZD caused bone marrow hypocellularity. Onuh et al. [33] also stated that date fruits returned bone marrow hypocellularity to its normal state and did not differ when compared with control group.

Brain

In Fig. 1e, normal brain tissue from control group showed normal neuron cells surrounded by neurological fibers with elongated vascular space filled with RBCs. After the $1^{\text {st }}$ day post-treatment with LZD, the brain tissue showed aggregates of inflammatory cells surrounding dilated vascular space (Fig. 1f), while the group treated with the combination of LZD and MEPD showed mild aggregates of inflammatory cells (Fig. 2a). On day-1 post-treatment, the group treated with MEPD revealed normal neuron cells and neurofilliary material (Fig. 2b).

These histopathological findings on the brain section of LZD-treated rats that showed aggregate of inflammatory cells; this is to indicate that LZD can highly penetrate CSF [34] and may be contributed to the axonal damage to sensory neurons that occur after LZD exposure [35]. LZD and Phoenix dactylifera combination showed mild aggregates

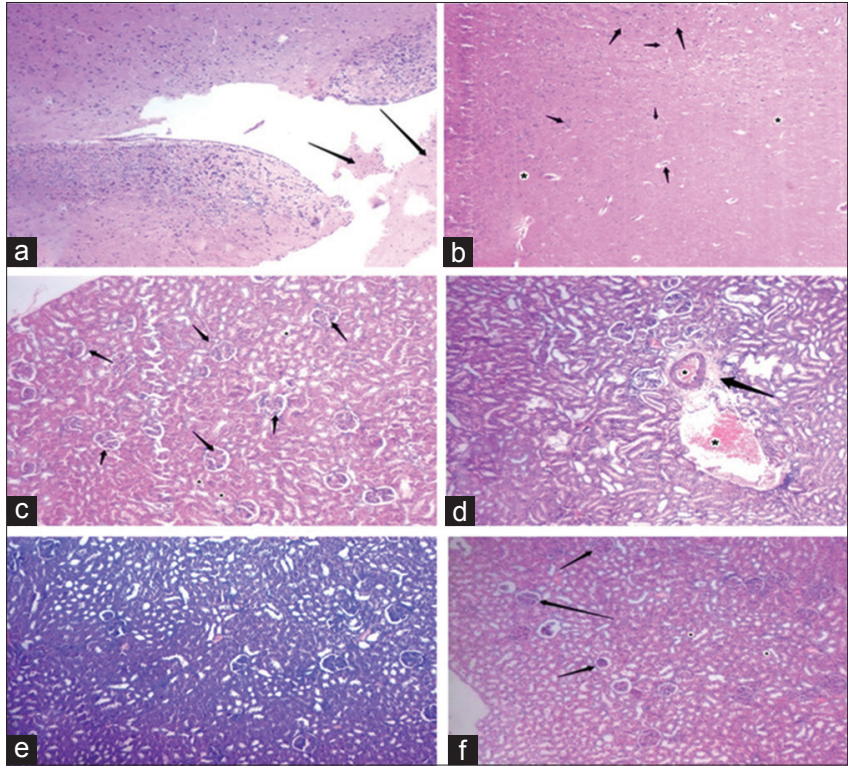

Fig. 2: (a) Photomicrograph of brain tissue from rats treated with LZD and Phoenix at day 1 post-treatment showed mild aggregates of inflammatory cells $\uparrow(H$ and $E, \times 200$ ). (b) Photomicrograph of brain tissue from rats at day 1 post-treatment with Phoenix showing normal neuron cells $\uparrow$ and neurofilliary material ${ }^{*}$ (H and E, × 200). (c) Photomicrograph of normal rat renal tissue of control group showing renal glomeruli $\uparrow$ and renal tubules* (H and E, $\times 200$ ). (d) Photomicrograph of renal tissue from rats

7 days post-treatment with LZD showing moderately dilated congested vascular space* and mild aggregates of inflammatory cells $\uparrow$ in between the glomeruli and tubules $(\mathrm{H}$ and $\mathrm{E}, \times 200)$. (e) Photomicrograph of renal tissue treated with LZD and Phoenix 7 days post-treatment showing normal glomeruli $\uparrow$ and tubules* (H and E, $\times 200$ ). (f) Photomicrograph of renal tissue treated with Phoenix showing normal glomeruli $\uparrow$ and tubules* $(\mathrm{H}$ and $\mathrm{E}, \times 200)$

of inflammatory cells. This results agreed with Agbon et al. [14], who concluded that PD fruits have neuroprotective effect due to its antioxidant properties.

\section{Kidney}

The kidney section of the control group showed normal renal glomeruli and renal tubules (Fig. 2c). The renal tissue showed moderately dilated congested vascular space and mild aggregates of inflammatory cells in between glomeruli and renal tubules on day 7 post-treatment with LZD alone (Fig. 2d). The combination of both LZD and MEPD led to the absence of inflammatory cells with return of the renal tissue to its normal state on day 7 post-treatment (Fig. 2f). On day-7, PD treated group showed that the renal tissue showed normal structure (Fig. 2e). These results were in accordance with Ahmed et al. [36], who concluded that the protection of PD seeds extract could be attributed to the total phenol/proanthocyanidin content, which can suppress the oxidative stress induced by xenobioticgenerating free radicals with the subsequent restoration of the physiological and histological features of the susceptible organs.

\section{CONCLUSION}

The current study reported that the oral administration of the therapeutic dose of LZD to male albino rats for 14 consecutive days resulted in damaging effects on the bone marrow, brain, and kidneys. It was evident that the concurrent oral administration of PD methanolic extract $(1000 \mathrm{mg} / \mathrm{kg} \mathrm{b}$ wt.) with LZD (100 mg/kg b wt.) clearly counteracted the cellular and biological damaging effects of LZD.

\section{CONFLICTS OF INTEREST}

All authors have no affiliations to any funded organization. 


\section{REFERENCES}

1. Brickner SJ, Hutchinson DK, Barbachyn MR, Manninen PR, Ulanowicz DA, Garmon SA, et al. Synthesis and antibacterial activity of U-100592 and U-100766, two oxazolidinone antibacterial agents for the potential treatment of multidrug-resistant gram-positive bacterial infections. J Med Chem 1996;39:673-9.

2. Ford CW, Hamel JC, Wilson DM, Moerman JK, Stapert D, Yancey RJ Jr., et al. In vivo activities of U-100592 and U-100766, novel oxazolidinone antimicrobial agents, against experimental bacterial infections. Antimicrob Agents Chemother 1996;40:1508-13.

3. Daly JS, Eliopoulos GM, Willey S, Moellering RC Jr. Mechanism of action and in vitro and in vivo activities of S-6123, a new oxazolidinone compound. Antimicrob Agents Chemother 1988;32:1341-6.

4. Swaney SM, Aoki H, Ganoza MC, Shinabarger DL. The oxazolidinone linezolid inhibits initiation of protein synthesis in bacteria. Antimicrob Agents Chemother 1998;42:3251-5.

5. Tenover FC, Arbeit RD, Goering RV, Mickelsen PA, Murray BE, Persing DH, et al. Interpreting chromosomal DNA restriction patterns produced by pulsed-field gel electrophoresis: Criteria for bacterial strain typing. J Clin Microbiol 1995;33:2233-9.

6. Gonzales RD, Schreckenberger PC, Graham MB, Kelkar S, DenBesten K, Quinn JP. Infections due to vancomycin-resistant Enterococcus faecium resistant to linezolid. Lancet 2001;357:1179.

7. Di Paolo A, Malacarne P, Guidotti E, Danesi R, Del Tacca M. Pharmacological issues of linezolid: An updated critical review. Clin Pharmacokinet 2010;49:439-47.

8. Beekmann SE, Gilbert DN, Polgreen PM; IDSA Emerging Infections Network. Toxicity of extended courses of linezolid: Results of an infectious diseases society of America emerging infections network survey. Diagn Microbiol Infect Dis 2008;62:407-10.

9. Baliga MS, Bantwal R, Vittaldas B, Shaun MK, Harshith PB, Praveen $\mathrm{K}$, et al. A review of the chemistry and pharmacology of the date fruits (Phoenix dactylifera L.). Food Res Int 2011;44:1812-22.

10. Mansouri A, Embarek G, Kokkalouc E, Kefalas P. Phenolic profile and antioxidant activity of the Algerian ripe date palm fruit (Phoenix dactylifera). Food Chem 2005;89:411-20.

11. Abedi A, Parviz M, Karimian SM, Rodsari S. The effect of aqueous extract of Phoenix dactylifera pollen grain on sexual behavior of male rats. J Phys Pharm Adv 2012;2:235-42.

12. Miller CJ, Dunn EV, Hashim IB. The glycaemic index of dates and date/yoghurt mixed meals. Are dates 'the candy that grows on trees'? Eur J Clin Nutr 2003;57:427-30.

13. Patel MI, Makhija SJ. Toxicity assessment of linezolid and the beneficial effects of human erythropoietin in mice. Eur J Exp Biol 2012;2:2172-81.

14. Agbon AN, Ingbian SN, Dahiru AU. Preliminary histological and histochemical studies on the neuroprotective effect of aqueous fruit extract of Phoenix dactylifera L. (Date Palm) on atesunate-induced cerebellar damage in wistar rats. J Med 2014;1:204-9.

15. Arbiol-Roca A, Imperiali CE, Montserrat MM, Cerro AS, Bosch de Basea AC, Navarro LS, et al. Reference intervals for a complete blood count on an automated haematology analyser sysmex $\mathrm{XN}$ in healthy adults from the Southern metropolitan area of Barcelona. EJIFCC 2018;29:48-54.

16. Patton C, Crouch G. Enzymatic colorimetric determination of urea. Anal Chem 1977;49:464-9.

17. Henry TJ. Determination of serum creatinine. In: Clinical Chemistry: Principles and Techniques. $2^{\text {nd }}$ ed. New York: Harper and Row Publishers; 1974.

18. Suvarnet S, Layton C, John BD. Bancroft's Theory and Practice of Histological Techniques. $7^{\text {th }}$ ed. Philadelphia, PA: Elsevier; 2013.
19. Snedecor GW, Cochran WG. Statistical Methods. $8^{\text {th }}$ ed. Iowa, USA: Ames, Iowa State University Press; 1982.

20. Nagel S, Köhrmann M, Huttner HB, Storch-Hagenlocher B, Schwab S. Linezolid-induced posterior reversible leukoencephalopathy syndrome. Arch Neurol 2007;64:746-8.

21. Rahmani AH, Aly SM, Ali H, Babiker AY, Srikar S, Khan AA, et al. Therapeutic effects of date fruits (Phoenix dactylifera) in the prevention of diseases via modulation of anti-inflammatory, anti-oxidant and antitumour activity. Int J Clin Exp Med 2014;7:483-91.

22. Dudzińska E, Gryzinska M, Ognik K, Gil-Kulik P, Kocki J. Oxidative stress and effect of treatment on the oxidation product decomposition processes in IBD. Oxid Med Cell Longev 2018;2018:7918261.

23. Birmingham MC, Rayner CR, Meagher AK, Flavin SM, Batts DH, Schentag JJ. Linezolid for the treatment of multidrug-resistant, grampositive infections: Experience from a compassionate-use program. Clin Infect Dis 2003;36:159-68.

24. MacDougall C, Chambers HF. Protein synthesis inhibitors and miscellaneous antibacterial agents. In: Brunton LL, Chabner BA, Knollmann BC, editors. Goodman and Gilman's The Pharmacological Basis of Therapeutics. 12 $2^{\text {th }}$ ed. New York: McGraw Hill; 2011. p. $1537-8$.

25. Ufelle SA, Achukwu PU, Ghasi SI. Myelo-protective and haematopoietic effects of seed extract fractions of Phoenix dactylifera in wistar rats. Afr J Pharm Pharmacol 2016;10:936-44.

26. Kofteridis DP, Malliotakis P, Maraki S, Christofaki M, Samonis G. Impact of prolonged treatment with linezolid on the human gut flora. Int J Infect Dis 2009;13:e313-5.

27. French G. Safety and tolerability of linezolid. J Antimicrob Chemother 2003;51 Suppl 2:245-53.

28. Mozos I. Mechanisms linking red blood cell disorders and cardiovascular diseases. Biomed Res Int 2015;2015:682054.

29. Natsumoto B, Yokota K, Omata F, Furukawa K. Risk factors for linezolid-associated thrombocytopenia in adult patients. Infection 2014;42:1007-12.

30. Nayak S, Nandwani A, Rastogi A, Gupta V. Acute interstitial nephritis and drug rash with secondary to linezolid. Indian J Nephrol 2012;22:367-9.

31. Al-Qarawi AA, Abdel-Rahman H, El-Mougy SA, Mousa HM, Badreldin HA. Nephroprotective action of Phoenix dactylifera in gentamicin-induced nephrotoxicity. Pharm Biol 2008;46:227-30.

32. Lin YH, Wu VC, Tsai IJ, Ho YL, Hwang JJ, Tsau YK, et al. High frequency of linezolid-associated thrombocytopenia among patients with renal insufficiency. Int J Antimicrob Agents 2006;28:345-51.

33. Onuh N, Ukaejiofo EO, Achukwu PU, Ufelle SA, Okwuosa CN, Chukwuka CJ. Haemopoietic activity and effect of crude fruit extract of Phoenix dactylifera on peripheral blood parameters. Int J Biol Med Res 2012;3:1720-3.

34. Villani P, Regazzi MB, Marubbi F, Viale P, Pagani L, Cristini F, et al. Cerebrospinal fluid linezolid concentrations in postneurosurgical central nervous system infections. Antimicrob Agents Chemother 2002;46:936-7.

35. Bobylev I, Maru H, Joshi AR, Lehmann HC. Toxicity to sensory neurons and Schwann cells in experimental linezolid-induced peripheral neuropathy. J Antimicrob Chemother 2016;71:685-91.

36. Ahmed AF, Al-Qahtani JH, Al-Yousef HM, Al-Said MS, Ashour AE, Al-Sohaibani $\mathrm{M}$, et al. Proanthocyanidin-rich date seed extract protects against chemically induced hepatorenal toxicity. J Med Food 2015;18:280-9. 